\title{
"YOU SHOULD BUILD FOR ETERNITY" \\ NEW LIGHT ON THE HITTITE ARCHITECTS AND THEIR WORK
}

\author{
Ahmet Unal \\ The University of Chicago
}

The title of my paper ${ }^{1}$ derives from a Hittite text. ${ }^{2}$ In another text the builders boast "to have used only the best quality of stone and timber" for their constructions. ${ }^{3}$ How many languages on earth can express such lofty and pretentious sentiments, and how many builders pursue such a high architectural goal? These expressions are in no way literary topoi. They are reflections of reality. This is clearly seen from the archaeological remains at Hittite cities, particularly at their capital Hattuš/Boğazköy. Without exalting the proficiency of the Hittite architects too much, I only wish to say that the Hittites were the first and most proficient builders of monumental stone architecture in pre-Classical Asia Minor. Because of their exaggerated obsession with stone and crag, they have justly been designated as "petromaniacs." How is one to explain this? Perhaps the answer lies in the stony, rocky ground of Anatolia, the most accessible building material around. From the foundation rituals found in the archives at Hattuša we know that the Hittites learned much from their subjects, the Hattians, who were the indigenous people of Anatolia. We can also justly say "Hatti capta ferrum cepit et victorem artes docuit." There are ample archaeological remains from the Early Bronze Age which illustrate the early Hattic building tradition. Needless to say, the Hittites inherited this tradition, modified it, and "magnified" its size, proportions, and dimensions. This was, of course, commensurate with their military and imperial power.

KUB 55.28, with its unpublished joining piece Bo 7740 from the Berlin Museum, ${ }^{4}$ certainly belongs to one of the most interesting texts published in recent years. It is a unique foundation ritual from the thirteenth century B.C., and sheds new light on Hittite architects at work. The text also shows, for the first time, their acrobatic skills as fearless stunt men. The

1. Paper read at the 197th annual meeting of the American Oriental Society in Los Angeles, March 1987.

2. KUB 31.100 obv. 10.

3. KUB $2.2 \&$ ii $50 \mathrm{ff}$.

4. Bo 7740, kindly sent to me by Professor $\mathrm{H}$. Klengel. 
archaeological remains and the landscape indicate clearly that the Hittites were dauntless climbers and avid builders who skillfully negotiated the jagged and rocky peaks at Hattuša, which is one of the craggiest capitals in the ancient world.

The text mentions sacrifices for the foundation stones and a magical formula which is spoken to ward off evil from the house. It must later have described the erection of pillars, which subsequently appear as already completely upright. Afterwards must have been mentioned the transportation of long timbers which were used as beams, joists, and roof battens for covering the flat roof. In rev. iii the workmen are lifting the beams to the roof. After that the architect climbs to the roof beams by means of a rope and, using a silver axe and silver knife, cuts off the loops. These loops have certainly been twisted around the wooden beams to serve as a lifting device, a pulley.

$$
\text { KUB } 55.26 \text { + Bo } 7740
$$

Obv. $i$

5.

$\begin{array}{ll}{[} & ] \\ {[} & z] i i^{5} \text { UDU.GE } \\ {[} & n u-m a] s-m a-s a-a s^{\natural} \\ {[} & -] a n \text { KUS.UDU } \\ {[} & k u-i] t \text { ? }-k a n \\ {[} & \quad] \text { UDU-ašan-da } \\ {[} & k] u-e-d a-n i-i k-k i\end{array}$

[sa-ma-ni or hal-hal-tu-ma-ri bu-ek-zi . . ] A-NA NA 4 an-da [ ] É-ir-za pa-ra-a pa-id-du

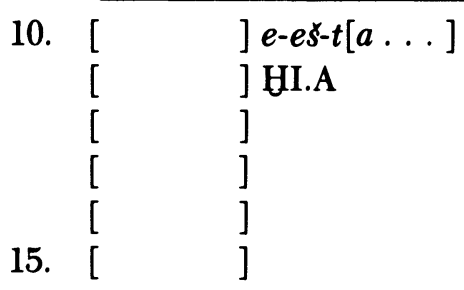

5. Sign looks like MAS, PAR, or QA.

6. Followed by an erasüre. 
Obv. ii

EN E-T[IM7 ku-e-da-ni šar-hu-li]

pi-ra-an a-še-eš-ša-an-z[a a-pi-e-da-ni]

sar-hu-li Ú-UL hu-kán-zi ZAG-na-az-z[i-ya?]

GÙB-la-az-zi-ya ku-iš sar-hu-li-is

5. nu-uŠ-sa-an a-pi-e-da-ni 3 AS̆-RA bu-kán-[zi]

$b[u-k] a ́ n-z i-m a-a s ̌-s a-a n k u-w a-p i-i t-t a$ I UDU

nu iš-ba-ni EGIR-an-da PA-NI ZAG.GAR.RA

KAS GESTIN si-pa-an-ti 2 sar-bu-li-ya-aš-sa

pi-ra-an ku-wa-pi-it-ta 3-SU si-pa-an-ti

10. $n u$ su-up-pa bu-i-su UZU.GAB.HI.A UZU.ZAG.UDU.HI.A

SAG.DU.MES GIR-ya PA-NI ZAG.GAR.RA ti-an-zi

A-NA sar-bu-li-ya-aš ku-e-da-aš bu-u-kán-ta

$n u^{8} a-p i-e-d a-a s-s a$ UZU.GAB.HI.A UZU.ZAG.UDU.HI.A

SAG.DU.MES GIR.MES ti-an-zi

15. nam-ma EGIR-an-da KAS GESTIN PA-NI ZAG.GAR.RA

3-SU si-pa-an-ti 3 sar-bu-li-ya-aš-sa-an

pi-ra-an ku-wa-pi-it 3-SU si-pa-an-[ti]

14-SU ir-ba-iz-zi GIS.DINGIR.INANNA TUR SIR-[RU]

U[ZU.NI]G.GIG UZU SẢ ba-ap[-pi-ni-it za-nu-an-zi]

(rest of column broken)

Rev. iii

nu $m\left[a\right.$ ? -ab-ba-an LÚ.MES ${ }^{9} \ldots$. . ]

GIŠ.in-n[a-aš-su-ušlo $b] u-i[t-t i-y a-a n-z i n u$ LÚ.NAGAR]

$k u-i s\left[I-N A(?)\right.$ E]-TIM ${ }^{11}$ ú-e-te-i[z-zi]

nu is-bi[-ma-na-a]n a-pa-a-as ar-ki-ya[-at-ta(-ri)]

5. na-aš-kán [iš-]ha-ma-na-an! ša-ra-a I[-NA GIŠ.UR(?)]

2-SU $p[a-i] z-z i^{12}$ kat-ta-ya-as-kán 2-[-SU pa-iz-zi]

$k u-i t-m a-[n] a-a n$ is-ha-ma-na-an ar-k[i-ya-at-ta(-ri)]

LÚ.MES.NAR-ma-kán ha-aš-ša-an bu-w[a-an-zi]

7. Bo 7740 joins here, and clearly indicates the upper edge of the tablet. From here on the line count is according to the joining piece.

8. Erasure.

9. According to the context we expect here as subject of the sentence some men working on the construction.

10. Restoration according to KUB 29.1 iii 14f.; see commentary, below.

11. H. G. Güterbock proposes the reading GIŠ. U]]R, which I cannot follow.

12. According to the traces another possible reading is $e-[i] p-z i$. 
I-NA 3 KAS[KAL]-NI[-ma SI] G.pid-du-la-a[n]

10. tub-sa- $[a-r] i^{13}$ ma-ah-ba-an-ma-kán LÚ.NAGAR

[SI]G.[p]id-du-la-an tu-ub-ša-a-ri

[LÚ.p]al-wa-at-tal-la-aš-sa [[LÚ]] ${ }^{14}$ pal-wa-a-iz-zi

[TÚG-aš]-ma-kán $k u$-iš IŚ-TU GIŠ.ÜR $k a t-t a{ }^{15}$

kán-kán-za PA-A-ŚU KÜ.BABBAR!16-kán GÍR KÙ.B[ABBAR]

15. ku-e-da-ni A-NA TÚG an-da iš-hi-ya-an-za

na-aš-ta a-pu-u-un-na TÚG-an ar-ha [tuh-ša-a-ri]

na-aš-ta LÚ.NAGAR iš-ba-ma-na-az

kat-ta ú-iz-zi na-as A-NA EN É-[TIM]

${ }^{17}$ US-KI-EN nu ma-a-an I-NA É-S[U pa-iz-zi]

20. nu-za GIS.PA-A-SU KÙ.BABBAR GÍR KÙ.B[ABBAR]

LÚ.NAGAR $d[a-a-i]$

(Lower edge)

Rev. iv

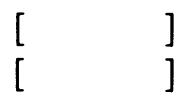

\begin{tabular}{l} 
ME]S?-si-kán ${ }^{18}$ \\
{$\left[\begin{array}{l}\text { I-N]A E.SAL.LUGAL } \\
{\left[-m u-u s^{19}\right.}\end{array}\right.$} \\
\hline
\end{tabular}

(Free space, then broken)

13. This emendation is necessary; the sign looks like MES.

14. According to $\mathrm{H}$. A. Hoffner, LU here, preceding palwai-, is a determinative on a verb denoting the action of a LÚ.palwaltallaš; compare LÚ.miyahuntešs- and SIG.mitešsi-. See also E. Neu, StBoT 5 (1968) 142; CHD 3/3 (1986) 304.

15. Over an erasure is written [IG]I?-zi?; it is hardly visible in the copy.

16. The second part of the sign shows TE instead of the expected UD.

17. Bo 7740 joins here.

18. Colophon of the tablet.

19. There follow traces of an erasure. 
Obv. $i i$

In front of [the pillar where] the owner of the house is sitti[ng, to] (this) pillar they do not sacrifice (any sheep). Bu[t] to the pillars (sg.) which are on the right and left (side of the owner of the house), to those they sacrifice (sheep) in three different places. Each time, however, they s[ac]rifice one sheep.

In front of the altar, he (the owner of the house) pours beer (and) wine after the blood (offering). In front of each of the two pillars they libate three times. They place the raw meat (of the sacrificed sheep), the breasts, shoulders, heads, and feet, in front of the altar. The breast, shoulders, heads, (and) feet they place in front of those $\mathrm{t}$ [wo] pillars, to (or for) which (animals) have been slaughtered.

Afterward he libates beer (and) wine three times before the altar. $\mathrm{He}$ (now) libates three times before each of the three pillars. He makes the rounds 14 times (around the pillars?). [They] play the small Ištar-instrument.

(rest of the column is broken)

Rev. iii

Wh[en the workmen h]a[ul] the be[ams] (up to the roof), [the architect] who builds [the hou]se is the one who [shall] climb up the r[op]e (to the roof). He g[o]es up the [ro]pe t[o the roof(?)] twice and [he goes] down twice. While [he is] climb[ing] it (that is, the rope), the singers $r$ [un] around the hearth.

The third time he (sc. the architect) cu[t]s the sling. When the architect cuts the [s]ling, the applauder claps his hands. But (there is) [a sash ${ }^{20}$ which is dangling from the roof beam. In this sash are bound an axe of silver (and) a knife of si[lver]. Now that sash too [he cuts(?)] off. Then the architect comes down by the rope and he bows to the owner of the house. When he [goes] to $h$ [is own] house, the architect $t$ [akes] the axe of silver (and) the knife of silver for himself (as his fee). 
Because of the laconic and cryptic character of the text a re-reading from the architectural point of view is necessary. I will restrict myself here to only a few important terms: GIŠ.šarbuli-, GIŠ.innašsa-,, and GIŠ.ÜR.

From a variant in a duplicate text, ${ }^{21}$ we know the Sumerian equivalent of GIŠ.sarhuli-, "pillar, column," 22 to be GIŠ.DIM, which also means both "pillar" and "column."23

Our text shows that there can be three pillars in one house or temple. If we are allowed to identify them functionally with pillars or posts rising above the stone foundations, supporting the superstructure of the upper mud brick walls and/or as corner poles or posts, archaeologically they must then be associated with the "pilasters which we have seen as rudimentary parts of buildings." 24 Their number, in our text three, corresponds with the number of the pillars in Temples I and II at Boğazköy; Peter Neve takes this a priori as a supporting argument for the identification of the pillars as sarbuli-. This side issue, however, has little significance for our subject, since the construction mentioned in our text is most probably a private house, not a temple; moreover, the number of pillars mentioned in it may be incidental. Indeed, another Hittite text clearly attests only one pillar in a temple. ${ }^{26}$ This can only mean the central pillar or column.We know also that hearth and pillar were very close to each other.

The best way to prove or disprove the identity of sarhuli- with pillars is to take a close look at the archaeological remains. On the evidence of stone bases ("Stïtzbasen, Pfeilerbasen") there are, for example, twelve of these pillars in two rows in Building A on Büyükkale (similarly in Gebäude K), each row including six pillars. Peter Neve thinks that these rectangular stone bases were for wooden poles, which supported wooden shelves arranged along the walls to hold cuneiform tablets. ${ }^{27}$ Because of the high number of bases and their proximity to each other, in both directions, Neve's interpretation seems to be acceptable. We must also compare the four flat stones found in the palace at Maşat Höyük, ${ }^{28}$ which obviously served as bases for columns or pillars.

21. KUB 41.3 i 7 .

22. Otten, IstMitt 19/20 (1969-70 [1971]) 90.

23. Hittite GIS.kurakki-; cf. Otten, IstMitt 19/20 (1969-70) 90f., with further literature.

24. P. Neve, Fs. Otten (1973) pp. 271f.: "Wandvorlagen, die wir als pfeilerähnliche, rudimentäre Bauglieder kennenlernten."

25. Neve, Fs. Otten pp. 271f.

26. KBo 17.15 obv? 13f. with its Old Hittite duplicate KBo 17.40 iv $7 \mathrm{ff}$.

27. Neve, Büyükkale, die Bauwerke (1982) 106, 108ff., and pls. 23b, 56a.

28. T. Ozgüç, Excavations at Maşat Höyük and Investigations in its Vicinity (1978) p. 55 and pls. 12-13. 
Some other Hittite texts testify that pillars were still clearly visible even long after the construction of the building was completed. This explains why in most cases they appear to receive sacrifices together with other architectural elements such as walls, hearths, windows, doors, door bolts, columns, altars, and so on. ${ }^{29}$

In the myth of Hedammu ${ }^{30}$ sarhuli- clearly denotes one or more poles supporting the throne or seat of Kumarbi, a construction like a trellis, bower (Turkish çardak), or a hunting stand (German Anstand). ${ }^{31}$

GIŠ.šarhuliyaš pedan, "place of the pillar," 32 can be understood as the holes or column bases on which the pillars were erected. The existence of a central sarhuli-, with an additional pillar on its right and left sides, is mentioned in another fragmentary text: "[He libates to] the right pillar once." 33 According to yet another fragmentary text the verb used to indicate the setting up of pillars is karp-, "to lift, erect (a pillar)." 34

As for the exact architectural position of pillars on the premises, the archaeological data permits two suggestions. The first possibility is that they were identical with the big pilasters which are integrated into the walls (Wandvorlagen).$^{35}$ The big cavities for these pilasters, which vary in thickness from 0.30 to 1.40 meters, can be seen in the brick walls from the palace at Maşat Höyük. ${ }^{36}$ These cavities are also clearly visible in the brick and stone walls of the temples in the Upper City at Bogazköy. ${ }^{37}$ The bigger cavities would, of course, have been filled with more pieces of timber. ${ }^{38}$ The second possibility is that they were identical with free-standing rows of columns in the middle of the rooms, one in the center of the room and two more on each side of it. These pillars were placed on stone bases or in deep holes, and the heavy axial beams rested on top of them. This would

29. M. Popko, Kultobjekte (1978) pp. $39 f$.

30. KUB 12.65 ii 10ff.; differently J. Siegelová, StBoT 14:50f.

31. See CHD s.v. sarbuli-b, forthcoming.

32. KBo 15.24+KBo 24.109 ii 30; KUB 33.59 ii 4; KBo 20.68 i 7; KBo 11.47 obv. i 5; KBo 30.182 obv. 114.

33. sarbuli ZAG[-na] 1-SU' 'sipanti', KUB 10.83 i $2 \mathrm{f}$.

34. VAT 7497 ii 1-4: (1) [. . .] aulin GIŠ.šarbulin (2) [ . . ] karappanzi kuitmanma (3) 'karappan'zi LÚ.NAR URU.Kaneš (4) [SIR-RU].

35. See R. Naumann, Architektur Kleinasiens ${ }^{2}$ (1971) pp. 86-108, especially 98 and Abb. 92.

36. See T. Ozgüç, Maşat Höyük pp. 54ff. pls. B1, C2, D2. Compare also the pre-Hittite palace at Acemhöyük.

37. See P. Neve, ArchAnz (1985) pp. 330,341, and fig. 19; ArchAnz (1986) p. 382 and fig. 17.

38. T. Özgüç, Maşat Höyük p. 55. 
explain the role of the central pillar in our text. Other texts mention only one sarbuli- (in the singular!), ${ }^{39}$ which must be identical with this one pillar. ${ }^{40}$ Another text, however, mentions four pillars ${ }^{41}$; this means that at least two of them were in the center of the room, assuming that they do not designate the four corner pillars. We can imagine that the bigger buildings needed many free-standing pillars as props for their earthen roofs; the size and number of these pillars no doubt depended on the dimensions of the building. ${ }^{42}$

The second term I want to treat is GIŠ.innašsa-, ${ }^{43}$ which has already been translated correctly as "beam." The verb huittiya-, "to pull, to haul," 44 accurately describes its transport up to the roof. Since the complete construction of a flat earthen roof requires at least three wooden architectural elements in addition to pillars, it remains to discover exactly which of them is indicated by GIŠ.innaša-. The elements in question are: (1) massive beams or lintels which rest on top of the walls, or, in the case of a larger building, on top of the pillars ${ }^{45}$ or columns (kurakki-), to help support the roof ${ }^{46} ;(2)$ joists or rafters, serving as proper coverage of the roof; and (3) roof battens, small tiny logs which form the topmost level of the roof. The wooden construction may then be covered by brush, scrub, branches, or the like, as well as with a heavy layer of clay and earth. ${ }^{47}$

39. Note in this connection that its Sumerian equivalent GIS.DIM always occurs in the singular.

40. For example KUB 7.2 i 13 with duplicate KUB 41.3 i 7; KBo 20.68 i 11; KBo 17.15 obv. 15 with duplicate KBo 17.40 rev. 7 (see above); KBo 11.47 i 4f.; KUB 10.83 i 2 ff.; KBo 15.24+KBo 24.109 iii $3 f f$, restored from its duplicate VAT 7497 ii 1.

41. KUB 2.2 rev. iii 38.

42. Such as suggested for Building $D$, the Audience Hall at Büyükkale.

43. Rev. iii 2. My restoration of this word comes from the well-known foundation ritual KUB 29.1 iii 14, 27, which offers the only other attestation of this word and is beyond any doubt.

44. The similarity with Turkish kiriş çekmek is striking.

45. See the commentary on sarhuli-.

46. Modern parallels exist in Anatolia; see J. A. Morrison, Alişar: A Unit of Land Occupance in the Kanak Su Basin of Central Anatolia (unpubl. Ph.D. diss., University of Chicago, 1939) p. 81: "If a room be small, the lintels rest directly on the walls, but in the case of large rooms, intermediate supports are necessary. There are posts of similar large, unsquared timbers. They rest on pediments of flat slabs of limestone and are surmounted by primitive capitals made of short sections of roughly squared logs. Where a roof is entirely supported by posts, as over large rooms, the walls can be replaced without removing the roof."

47. The best way to understand these different layers is to look in a reference work such as A. Auranche, Dictionaire illustré multilingue de l'architecture du Proche Orient Ancien (1977) pp. 146 and 160 , with illustrations. 
We may posit that the beams (innaša-) were the biggest of these timbers, since their important function is indicated in our text by the ritual aspects of their installation, culminating in the architect's acrobatic activities. This thesis is indirectly supported by an account detailing the payment of workmen who were in charge of cutting and transporting GIS.innaša-. According to this record the carpenter who goes to the mountain to cut the necessary beams takes from the palace one bull, three sheep, three pitchers of wine, some other drinks, and loaves, to cover his fee and subsistence requirements. ${ }^{48}$ If the same carpenter, engaged in a similar task, instead goes to the forest and cuts GIS.iskišsana- and GIŠ.isparuzzi-, he gets as his fee only some sort of loaves. ${ }^{49}$ We thus learn that the cutting and transporting of innaša- was more cumbersome than that involving the other two types of timber; in fact, the wage for cutting innašsa- is equal to the wage of an agricultural workman for four months. ${ }^{50}$ We may therefore conclude that innaša- were the biggest and most important elements in the construction of Hittite roofs, and were almost certainly "beams." Because of their size and length they may not have been available in the forests close to Hattusa, and may therefore have had to be transported from the distant forests of the Black Sea region. The other two timber elements mentioned in this text, GIS.iškišsana- and GIŠ.isparuzzi-, can then be identified with joists and roof battens. ${ }^{51}$ The only way to understand their function is to connect them etymologically with iskisa-, "back," and isparr-, "to spread." Using these etymological comparisons, the joists would represent the "backside" or top of the building, while isparuzzi-, a hapax legomenon, would be named from the technique of stretching out and irregularly spreading small wooden pieces at the top of the roof, to serve as a kind of interweaving or webbing, on top of which a massive clay layer was heaped up (puruttai-) and then leveled.

GIŠ. ÙR in rev. iii 13 (read gušūru or $\bar{u} r u$ as a Sumerian loanword in Akkadian) could be equated with either GIS.innaša- or GIŠ.iskišsana-.

48. KUB 29.1 ii 13f.: man kuwapi kuwapi URU-ri E.GAL-LIM wetezzi nu kuis LÚ.NAGAR ISSSI HUR.SAG GIŠ.innašsaš karšuwanzi paizzi nu ISTU E.GAL-LIM 1 GUD.MAH 3 UDU.HI.A 3 DUG GESTIN 1 DUG marnuwan 10 NINDA.wagešsar 20 NINDA.KAXUD 50 NINDA.ERIN.MES-ya dai.

49. KUB 29.1 iii $18 \mathrm{ff}$.

50. See G. Kellerman, Recherche sur le rituels de fondation hittites (unpub. diss., Univ. of Paris, 1980)] p. 56.

51. GIS.iskišana- in Law no. 171, a kind of "article of furniture," is difficult to interpret. 
KBo 30.118 rev. 4 would not challenge these equations, since there we must most probably read E.GIS.ÜR.RA, not GIS.ÜR-ra. ${ }^{52}$ E.GIS.ÜR.RA is a hapax legomenon in both the Bogazköy texts and in Sumerian; it can, however, only designate a house made of wooden beams, a "log cabin." Although the tablet is too fragmentary to gain any further information, the term is the first attestation of a kind of architectural construction which must have been prevalent in the northern, Kaskean, regions of Asia Minor..$^{53}$ Even today this type of construction is the predominant form of dwelling in the richly forested Bolu and Black Sea regions, and in the Taurus mountains.

Finally, according to our text, $a^{-54}$ (iii 4,18 ) definitely means "to climb," since its opposite (in iii 18) is katta uwa-, "to come down." This affects our understanding of the passage KUB $29.128 \mathrm{ff}$., by making it unnecessary to translate "but the bear would couple up against you," 55 while at the same time confirming the meaning of hartagga- as "bear," a climbing animal.

Requiring the builder or architect to climb the rope up to the ceiling must have served a double purpose, cultic as well as practical. It was cultic because the act is an integral part of the foundation ritual; at the same time it was practical and secular because the builder takes possession of the silver axe and knife. Although acrobatics are known from other Hittite texts, this type of cultic-acrobatic performance is only attested in this text; as far as I know, it does not occur in either Mesopotamia or Egypt. ${ }^{58}$

52. Compare CAD G 144, which gives both writings GIŠ.ÙR and GIŠ.ÙR.RA, and AHw s.v. üru.

53. See J. Yakar - J. L. Garzon, Expedition 18 (1976) 43ff.; Handan Alkım, Fs. Bittel (1983) pp. 13-27.

54. KUB 55.28+ iii 4, 18.

55. J. Puhvel, HED 1-2 (1984) 142.

56. To gain an overview of games and acrobatics $I$ have checked the texts and collected the material, which can be subdivided as referring to agonistic games (which include ritual fighting, archery, boxing, and wrestling) and sports competitions (including running, throwing and catching, and many kinds of dances); I will discuss these in detail in a forthcoming article. It seems very modern that the winners of all these competitions are rewarded. The strange thing is, however, that the ones who failed were severely punished and jeered at. 